\title{
EDITORIAL
}

\section{Low molecular weight pollutants and asthma: pathogenetic mechanisms and genetic factors}

\author{
C.E. Mapp*, M. Saetta*, P. Maestrelli*, A. Ciaccia**, L.M. Fabbri**
}

\begin{abstract}
Most studies suggest that asthma prevalence has been increasing in children and young adults over the last four decades [1-4]. This increase is not confined to asthma but includes atopic diseases, such as hay fever and eczema. It has been suggested that a disease is caused by the interaction of genetic susceptibility and an adverse environment [5]. Environmental differences may explain the variations in the prevalence of asthma found in western countries. Several studies have shown an association between the risk of developing respiratory allergy and the season of birth [6]. Other environmental factors, such as respiratory viral infection, tobacco smoke and outdoor pollutants, have been considered as adjuvants for initial sensitization in childhood [7]. An adverse environment does not necessarily imply an outdoor environment, but could be the workplace where a subject spends a substantial part of his life.

Many investigators have sought a relationship between air pollution and asthma, but results are conflicting [810]. Different approaches, mainly epidemiological and laboratory studies, may be used to address this important question. The effects of exposure cannot always be reproduced experimentally, and likewise the effects obtained in the laboratory often do not have confirmation in epidemiological studies.

The role of air pollution in asthma remains difficult to assess, since although some major air pollution episodes have affected asthmatic subjects, others have had little effect on asthmatics [11]. Moreover, massive exposures to allergen, such as soybean allergen, have explained epidemics of asthma [12], and exposure to allergen may be a potential confounding factor in the interpretation of air pollution episodes.

Theoretically, air pollutants have the ability to exacerbate existing asthma and to increase the risk of developing asthma. From the data available on the effects of air pollutants, it is possible to say that pollutants may act in different ways: a direct irritant effect on hypersensitive airways; a direct toxic effect, mainly on the epithelium; the generation of an inflammatory process in the airways; and the modification of the immune response [13].
\end{abstract}

\footnotetext{
*Institute of Occupational Medicine, University of Padova, Italy. **Institute of Infectious and Respiratory Diseases, University of Ferrara, Italy. Correspondence: E. Mapp, Instituto di Medicina del Lavoro, Università degli Studi di Padova, via Facciolati 71, 35127 Padova, Italy.
}

The major low molecular weight air pollutants are sulphur dioxide, nitrogen dioxide and ozone. Considerable interest has been focused on the effects of these pollutants on airways, and extensive literature is available including epidemiological and experimental studies [1417].

Another important fact is that many cases of asthma in adults result from contact with industrial materials. Disease prevalence varies markedly depending on the industry. Even so, low molecular weight agents do appear to play an important role. Our research in this field has allowed us to increase our knowledge on the mechanism of action of low molecular weight agents, and on the similarities and discrepancies between occupational and nonoccupational asthma. Recently, CHAN-YeUnG and MALO [18] have reviewed the topic of aetiological agents in occupational asthma. In their extensive and complete review, they have also included low molecular weight agents, such as acid anhydrides, metals, pharmaceutical products, diisocyanates, western red cedar, amines and others.

In this paper, we will describe the effects of toluene diisocyanate (TDI) on airways, as an example of asthma induced by low molecular weight agents. In addition, we will provide evidence that occupational asthma induced by exposure to low molecular weight agents shares many features with nonoccupational asthma.

\section{The immune response}

In many cases, the pathogenetic mechanisms involved in occupational asthma remain to be determined. Immediate type I immunoglobulin E (IgE)-mediated hypersensitivity is involved in occupational asthma caused by high molecular weight agents, and in a number of cases of occupational asthma induced by low molecular weight agents [19].

Foreign substances that elicit an immune response are called antigens. The immune system is a sophisticated defence system, and it works through two types of defence. Circulating proteins, called antibodies or immunoglobulins bind to antigens and inactivate them. These antibody-mediated responses are referred to as "humoral immunity". In the second type of response, specialized cells with surface receptors capable of recognizing specific antigens, attack and destroy those antigens. This 
second type of defence is called "cellular immunity". The fact that a substance is foreign, does not necessarily mean it is antigenic. Infact, an antigen must be a macromolecule or be built up from macromolecules. Many high molecular weight agents present in the workplace fulfil the criteria, and are antigenic. On the contrary, small molecules by themselves can seldom produce specific circulating antibodies. However, many small molecules may change the antigenic properties of a larger molecule, i.e. a protein, when covalently coupled to it (haptens). The resulting antibodies are partially directed against the small molecule.

Immune responses are carried out by lymphocytes. Two major classes of lymphocytes exist, B-lymphocytes that synthesize antibodies and T-lymphocytes that carry out cellular immune responses. For the final differentiation of a B-cell, other cells besides the competent virgin B-cell are required. In most cases, T-lymphocytes called helper cells are also present. They interact with antigens by using their T-cell receptors. The antigens have been taken up and presented to them by accessory cells called antigen-presenting cells (APC). Helper Tcells are required for all immunoglobulin $G, E$ and $A$ (IgG, IgE, and $\operatorname{IgA}$ ) immune responses. The biological significance of the presence of helper T-cells could be that they are a means of regulating both the process of antibody synthesis and the B-cell division. In this regulation, suppressor T-cells also participate, in that they can block the proliferation and the terminal differentiation of B-cells.

Cytotoxic T-cells carry antigen-specific surface T-cell receptors, which see antigens only if the T-cell simultaneously sees normal cell surface proteins. T-cells see normal surface proteins coded for by the major histocompatibility complex (MHC). Whereas cytotoxic Tcells look at proteins coded for by class I MHC genes, helper T-cells look at proteins of class II MHC genes. The MHC complex encodes the cell surface protein that are essential for the T-cell function. Moreover, the class I and II MHC gene products have structural similarity to antibodies.

\section{Isocyanates: characteristics and uses}

Polyurethanes result from the reaction between an alcohol and an isocyanate (OCN-R'-NCO). The isocyanate group (-NCO) can react with any compound containing "active" hydrogen atoms, and diisocyanates may be used to modify many other products. Several aromatic and aliphatic diisocyanates are available, but $95 \%$ of all polyurethanes are based upon two aromatic diisocyanates, toluene diisocyanate (TDI) and diphenylmethane diisocyanate (MDI). Most of the TDI is a mixture of 2,4 and 2,6 isomers. The 80:20 mixture of the 2,4 and 2,6 isomers is the most important commercial product. Toluene diisocyanate is liquid at room temperature, is colourless, and has a molecular weight of 174.16.

Isocyanates have a wide application in the industrial and domestic environment. The prevalence of TDI- induced asthma has been reported to be 5-10\% [20]. Prepolymers of isocyanates have also been shown to induce asthma [21].

\section{The immune response in isocyanate-induced asthma}

So far, we have described the basic concepts in the generation of an immune response, and according to these concepts toluene diisocyanate may be considered as a foreign substance, but since it is a small molecule, it is likely that by itself it is not antigenic. Isocyanates are very reactive molecules, reacting with polyols, water, amines, and, under suitable conditions, with the active hydrogen atoms of the urethane and urea linkage to form biuret and allophanate linkages. It is not known what happens in vivo after inhalation of toluene diisocyanate, and which reactions occur between TDI and components of the body (proteins, water). The characteristics of asthma induced by isocyanates suggest an immunological mechanism, but only a small percentage of individuals with asthma have been shown to have type I hypersensitivity reactions, as documented by the finding of tolyl-specific IgE antibodies [22]. More recently, specific IgG antibodies have been shown in subjects with isocyanate-induced asthma [23].

Cell-mediated immunity may play a role in low molecular weight agent-induced asthma. Increased numbers of activated CD25+ T-lymphocytes, activated eosinophils and mast cells have been shown in bronchial biopsies from subjects with asthma induced by exposure to TDI [19].

\section{Genetic factors in isocyanate-induced asthma}

Genetic factors control human immune responses. It has been shown that human leukocyte antigen (HLA) complex products or genes may represent either a risk or a protective factor in the development of allergic asthma [24]. Recently, in a collaborative study with BIGNON et al. [25], we carried out HLA typing in isocyanate-induced asthma, and found that the allelic combination DQB $1 * 0503$ was associated with susceptibility to the disease, and that the allelic combination DQB $1 * 0501$ was associated with resistance to the disease.

More recently, we confirmed these results and extended our observations [26]. We found the presence, at the 57 position, of aspartic acid in DQB $1 * 0503$ allele and valine in DQB $1 * 0501$ allele, and suggested that the residue 57 of HLA-DQB1 could be used in risk assessment of isocyanate-induced asthma. Antigens are seen in the context of MHC gene products, and individual differences may alter the ability of the HLA class II molecules to interact with peptides, and, as a consequence, the nature of T-cell recognition may also be different. We do not know whether isocyanates are involved in antibody binding, or, more likely, being very reactive compounds, in the induction of structural changes of a body protein, causing a $\mathrm{T}$-cell mediated immune response. 
Responsiveness to foreign substances is linked to DQ alleles through the activation of CD4+ T-cells, that in turn might activate CD8+ suppressor T-cells. The immune system provides specific defence against foreign substances that enter the body. It is likely that the two types of responses referred to as humoral and cellular immunity co-exist, and when circulating antibodies are present, a cellular response is often demonstrable.

Isocyanate-induced asthma, on the basis of the preliminary results described above, may be considered an example of interaction of genetic factors with an adverse environment. In this type of asthma, there is evidence that both humoral and cellular immunity may play a role.

\section{Isocyanate-induced asthma as an inflammatory disease}

The pathology of bronchial asthma shows a multicellular process. T-lymphocytes are implicated in allergic, intrinsic and occupational asthma. Allergic inflammation is characterized by the IgE-dependent activation of mast cells and local accumulation of eosinophils [27]. Eosinophilic inflammation may be amplified by the granulocyte-macrophage colony-stimulating factor (GM-CSF). T-lymphocytes control IgE synthesis: the T-cell derived cytokines interleukin-4 (IL-4) and interferon-gamma (IFN- $\gamma$ ) are important in initial isotype switching and in other subsequent steps [28, 29]. Immunohistological studies of bronchial biopsies have shown T-lymphocyte activation in allergic, intrinsic and isocyanate-induced asthma [30-32]. Eosinophil inflammation is well-represented in TDI-induced asthma. Eosinophils are partially degranulated and present markers of activation [33]. Mononuclear cells and mast cells are also increased. Mast cells are increased to a greater extent mainly in subjects who develop asthma after few years of exposure [34]. The thickness of the reticular basement membrane is increased [33]. The pathology of isocyanate-induced asthma shares many features of nonoccupational asthma, i.e. IgE-mediated and intrinsic asthma. The pathology of other inflammatory airway diseases, such as chronic bronchitis, is quite different: mononuclear cells are increased but there is no subepithelial fibrosis [35].

We also found that the cessation of exposure to TDI was associated with a reduced thickness of subepithelial fibrosis [36] and with a reduced number of subepithelial fibroblasts, mast cells and lymphocytes in the bronchial submucosa [37]. Remarkably, parallel to the decrease in the number of fibroblasts was the decrease in the number of mast cells and lymphocytes, cells that enhance the synthesis of collagen by fibroblasts through the secretion of several cytokines [37]. Recently, it has been shown that marked inflammatory changes are present in the bronchial biopsies of subjects with occupational asthma after withdrawal from the exposure to the sensitizing agent. The type and extent of airway inflammation were not different according to whether asthma was induced by high or low molecular weight agents and regardless of the duration of asthma symptoms, as shown by BOULET et al. in this issue of the Journal [38].

That exposure to TDI in sensitized subjects causes recruitment and activation of inflammatory cells is further substantiated by the finding of an increase in circulating CD8+ T-cells and eosinophils 48-72 h after exposure to TDI in the laboratory; time-points at which bronchoconstriction has already disappeared [39]. Eosinophils also increase in the sputum of subjects with TDI-induced asthma [40]. A role for suppressor T-cells in isocyanate-induced asthma has recently been confirmed [41]. We observed that the majority of T-cell clones derived from subjects with TDI-induced asthma are CD8+, capable of producing interleukin-5 (IL-5) but not interleukin-4 (IL-4). The first cytokine attracts, activates and increases the survival of eosinophils, whereas the second stimulates IgE production. Suppressor Tcells seem to play a central role in isocyanate-induced asthma, as they probably do in intrinsic asthma [42].

Interestingly, the most common asthmatic reaction observed after exposure to isocyanates is the late asthmatic reaction, in which airway inflammation is important [43]. In the supernatant of bronchoalveolar lavage (BAL) fluid obtained from subjects with a late asthmatic reaction induced by exposure to isocyanates, there is an increased concentration of albumin [44, 45]. An increased number of neutrophils and of eosinophils, an increase in leukotriene $\mathrm{B}_{4}\left(\mathrm{LTB}_{4}\right)$ and an increase in nonspecific airway responsiveness are also associated with the late asthmatic reaction induced by isocyanates, suggesting the development of an acute inflammatory process in the airways [43-46]. The influx of leukocytes, the increase of albumin and of $\mathrm{LTB}_{4}$ are all prevented by pretreatment with steroids [45].

Release of peptides from sensory nerves in the airways may result in inflammation of the airways. Substance$\mathrm{P}$ (SP) and neurokinin (NKA) belong to the family of tachykinins, and activate different subtypes of receptors. Several inflammatory responses are mediated by neurokinin-1 $\left(\mathrm{NK}_{1}\right)$-receptors [47]. Tachykinins are degraded by neutral endopeptidase (NEP), which is localized mainly at the airway epithelium.

An increased amount of $\mathrm{NK}_{1}$-receptor messenger ribonucleic acid (mRNA), probably due to the effect of various cytokines on NK1-receptor gene transcription, has been described in asthmatic lungs [48]. Whether neurogenic inflammation is important in asthma remains to be determined. It is likely that neural mechanisms contribute to the pathophysiology of asthma. We have shown that toluene diisocyanate contracts rat and guinea-pig smooth muscle, in vitro, through the activation of the efferent function of capsaicin-sensitive primary afferents [49, 50]. Toluene diisocyanate-induced contractions in isolated guinea-pig airways are associated with increased levels of prostanoids, i.e. prostaglandin (PG) $\mathrm{F}_{2 \alpha}$ and 6-keto-PG $\mathrm{F}_{1 \alpha}$ [51]. We also found that TDI and capsaicin produce both shortening and relaxation in isolated human bronchi through $\mathrm{NK}_{1}$-receptors [52]. As in nonoccupational asthma, the role of neurogenic inflammation in occupational asthma remains to be proved. 
In conclusion, the association between exposure to outdoor pollutants and asthma is still far from clear and difficult to assess. As regards the association between indoor pollutants, in particular low molecular weight agents present in the workplace, there is experimental evidence to suggest that these agents cause asthma which has similar mechanisms, pathology, and association with specific HLA phenotypes, to extrinsic asthma.

Acknowledgements: Supported by the National Research Council (FATMA 93.00650 PF41 and Bilateral Project USA-Italy 94.02443.CT04), the CNR-ENEL Project-Interactions of Energy Systems with Human Health and Environment - Roma, the MURST (40\% and $60 \%$ ), the Regione Veneto, the European Community for Coal and Steel and A.R.C.A. Association. The authors thank P. Bortolami and L. Zedda for technical assistance, C. Howarth for editing the manuscript.

\section{References}

1. Aberg N. Asthma and allergic rhinitis in Swedish conscripts. Clin Exp Allergy 1989; 19: 59-63.

2. Haahtela T, Lindholm H, Bjorksten F, Koskenvuo K, Laitinen LA. Prevalence of asthma in Finnish young men. Br Med J 1990; 301: 266-268.

3. Burr ML, Butland BK, King S, Vaughan-Williams E. Changes in asthma prevalence: two surveys 15 years apart. Arch Dis Child 1989; 64: 1452-1456.

4. Burney PGJ, Chinn S, Roma RJ. Has the prevalence of asthma increased in children? Evidence from the national study of health and growth 1973-1986. $\mathrm{Br}$ Med J 1990; 300: 1306-1310.

5. Burney PGJ. Current questions in the epidemiology of asthma. In: Holgate ST, Austen KF, Lichtenstein LM, Kay AB, eds. Asthma. Physiology, Immunopharmacology and Treatment. London, Academic Press, 1993; pp. 3-16.

6. Warner JO, Price JF. House dust mite sensitivity in childhood asthma. Arch Dis Child 1978; 53: 710713.

7. Burney PGJ. Evidence for an increase in atopic disease and possible causes. Special article. Clin Exp Allergy 1993; 23: 484-492.

8. Anderson HR. Respiratory abnormalities in Papua New Guinea children: the effects of locality and domestic wood smoke pollution. Int J Epidemiol 1978; 7: 63-71.

9. Ishizaki T, Koizumi K, Ikemori R, et al. Studies of prevalence of Japanese cedar pollinosis among the residents in a densely cultivated area. Ann Allergy 1987; 58: 265-270.

10. Sultz HA, Feldman JG, Schlesinger ER, Mosher WE. An effect of continued exposure to air pollution on the incidence of chronic childhood allergic disease. Am J Public Health 1970; 60: 891-900.

11. Wichmann HE, Mueller W, Allhoff P, et al. Health effects during a smog episode in West Germany in 1985. Environ Health Perspect 1989; 79: 89-99.

12. Anto JM, Sunyer J, Rodriguez-Rosin R, Suarez-Cervera M, Vazquez L. Community outbreaks of asthma associated with inhalation of soybean dust. $N$ Engl J Med 1989; 320: 1097-1102.

13. Wardlaw AJ. The role of air pollution in asthma. Clin Exp Allergy 1993; 23: 81-96.

14. Utell MJ, Samet JM. Particulate air pollution and health. Editorial. Am Rev Respir Dis 1993; 147: 1334-1335.
15. Samet JM, Marbury MC, Spengler JD. Health effects and sources of indoor air pollution. Part I. State of Art. Am Rev Respir Dis 1987; 136: 1486-1508.

16. Samet JM, Marbury MC, Spengler JD. Health effects and sources of indoor air pollution. Part II. State of Art. Am Rev Respir Dis 1987; 137: 221-242.

17. Molfino NA, Wright SC, Katz I, et al. Effect of low concentrations of ozone on inhaled allergen responses in asthmatic subjects. Lancet 1991; 338: 199-203.

18. Chan-Yeung M, Malo JL. Aetiological agents in occupational asthma. Eur Respir J 1994; 7: 346-371.

19. Mapp CE, Saetta M, Maestrelli P, et al. Mechanisms and pathology of occupational asthma. Eur Respir $J$ 1994; 7: 544-554.

20. Butcher BT, Mapp CE, Fabbri LM. Polyisocyanates and their prepolymers. In: Bernstein IL, Chan-Yeung M, Malo JL, Bernstein DI, eds. Asthma in the Workplace. New York, Marcel Dekker, 1993; pp. 415-437.

21. Vandenplas O, Malo JL, Saetta M, Mapp CE, Fabbri LM. Occupational asthma and extrinsic alveolitis due to isocyanates: current status and perspectives. $\mathrm{Br} J$ Ind Med 1993: 50: 213-228.

22. Butcher BT, O'Neil CE, Reed MA, Salvaggio JE. Radioallergosorbent testing of toluene diisocyanatereactive individuals using p-tolyl isocyanate antigen. $J$ Allergy Clin Immunol 1980; 66: 213-216.

23. Cartier A, Grammer L, Malo JL, et al. Specific serum antibodies against isocyanates: association with occupational asthma. J Allergy Clin Immunol 1989; 8: 507-514.

24. Marsh DG, Hsu SH, Roebber M, et al. HLD-Dw2: a genetic marker for human immune response to short ragweed pollen allergen Ra5. J Exp Med 1982; 155: 1439-1451.

25. Bignon JS, Aron Y, Ju LY, et al. HLA class II alleles in isocyanate-induced asthma. Am J Respir Crit Care 1994; 149: 71-75.

26. Balboni A, Fabbri LM, Mapp CE, et al. Presence of DQB1 alleles with aspartic acid in position 57 is a risk factor for isocyanate-induced asthma in exposed workers. Hum Immunol 1994; 59: 147.

27. Djukanovic R, Roche WR, Wilson JW, et al. Mucosal inflammation in asthma. State of art. Am Rev Respir Dis 1990; 142: 434-457.

28. Del Prete G, Maggi E, Parronchi P, et al. IL-4 is an essential factor for the IgE synthesis induced in vitro by T-cell clones and their supernatants. J Immunol 1988; 140: 4193-4198.

29. Snapper CM, Paul WE. Interferon- and B-cell stimulatory factor- 1 reciprocally regulate Ig isotype production. Science 1987; 236: 944-947.

30. Bentley AM, Maestrelli P, Saetta M, et al. Activated T-lymphocytes and eosinophils in the bronchial mucosa in isocyanate-induced asthma. J Allergy Clin Immunol 1992; 89: 821-829.

31. Corrigan CJ, Hamid Q, Kay AB. T-lymphocytes and the pathogenesis of bronchial asthma: studies using the techniques of in situ hybridization and polymerase chain reaction cDNA amplification. In: Holgate ST, Austen KF, Lichtenstein LM, Kay AB, eds. Asthma. Physiology, Immunopharmacology and Treatment. London, Academic Press, 1993; pp. 153-162.

32. Corrigan CJ, Kay AB. CD4+ T-lymphocyte activation in acute severe asthma. Relationship to disease severity and atopic status. Am Rev Respir Dis 1990; 141: 970-977.

33. Saetta M, Di Stefano A, Maestrelli P, et al. Airway mucosal inflammation in occupational asthma induced 
by toluene diisocyanate. Am Rev Respir Dis 1992; 145: $160-168$.

34. Di Stefano A, Saetta M, Maestrelli P, et al. Mast cells in airway mucosa and rapid development of occupational asthma induced by toluene diisocyanate. Am Rev Respir Dis 1993; 147: 1005-1009.

35. Saetta M, Di Stefano A, Maestrelli P, et al. Activated T-lymphocytes and macrophages in bronchial mucosa of subjects with chronic bronchitis. Am Rev Respir Dis 1993; 147: 301-306.

36. Saetta M, Maestrelli P, Di Stefano A, et al. Effect of cessation of exposure of toluene diisocyanate (TDI) in bronchial mucosa of subjects with TDI-induced asthma. Am Rev Respir Dis 1992; 145: 169-174.

37. Di Stefano A, Maestrelli P, Mapp CE, et al. The reduction of airway subepithelial fibrosis after cessation of exposure to toluene diisocyanate (TDI) in sensitized subjects is associated with a reduction of mast cells and fibroblasts. Am Rev Respir Dis 1993; 147: A557.

38. Boulet LP, Boulet M, Laviolette M, et al. Airway inflammation after removal from the causal agent in occupational asthma due to high and low molecular weight agents. Eur Respir J 1994; 7: 1567-1575.

39. Finotto $\mathrm{S}$, Fabbri LM, Rado $\mathrm{V}$, et al. Increase in numbers of CD8 positive lymphocytes and eosinophils in peripheral blood of subjects with late asthmatic reactions induced by toluene diisocyanate. $\mathrm{Br} J$ Ind Med 1991; 48: 116-121.

40. Maestrelli P, Calcagni PG, Saetta M, et al. Sputum eosinophilia after asthmatic responses induced by isocyanates in sensitized subjects. Clin Exp Allergy 1994; 24: 29-34.

41. Maestrelli P, Del Prete GF, De Carli M, et al. CD8 $\mathrm{T}$-cell clones producing interleukin-5 and interferongamma in bronchial mucosa in toluene diisocyanate asthma. Scand J Work Environ Health 1994; (in press).

42. Walker C, Bode E, Boer LL, et al. Allergic and nonallergic asthmatics have distinct patterns of T-cell activation and cytokine production in peripheral blood and bronchoalveolar lavage. Am Rev Respir Dis 1992; 146: 109-115.
43. Mapp CE, Polato R, Maestrelli P, et al. Time course of the increase in airway responsiveness associated with late asthmatic reactions to toluene diisocyanate in sensitized subjects. J Allergy Clin Immunol 1985; 75 : 568-572.

44. Fabbri LM, Boschetto P, Zocca E, et al. Bronchoalveolar neutrophilia during late asthmatic reactions induced by toluene diisocyanate. Am Rev Respir Dis 1987; 136: 36-42.

45. Boschetto P, Fabbri LM, Zocca E, et al. Prednisone inhibits late asthmatic reactions and airway inflammation induced by toluene diisocyanate in sensitized subjects. J Allergy Clin Immunol 1987; 80: 261-267.

46. Zocca E, Fabbri LM, Boschetto P, et al. Leukotriene $\mathrm{B}_{4}$ and late asthmatic reactions induced by toluene diisocyanate. J Appl Physiol 1990; 68: 1576-1589.

47. Barnes PJ. Neural mechanisms in asthma. In: Holgate ST, Austen KF, Lichtenstein LM, Kay AB, eds. Asthma. Physiology, Immunopharmacology and Treatment. London, Academic Press, 1993; pp. 259-273.

48. Peters MJ, Adcock IM, Gelder CM, et al. $\mathrm{NK}_{1}$ receptor gene expression is increased in asthmatic lung and reduced by corticosteroids. Am Rev Respir Dis 1992; 145: A835.

49. Mapp CE, Chitano P, Fabbri LM, et al. Evidence that toluene diisocyanate (TDI) activates the efferent function of capsaicin-sensitive primary afferents. Eur J Pharmacol 1990; 180: 113-118.

50. Mapp CE, Graf PD, Boniotti A, Nadel JA. Toluene diisocyanate contracts guinea-pig bronchial smooth muscle by activating capsaicin-sensitive sensory nerves. J Pharmacol Exp Ther 1991; 256: 1082-1085.

51. Mapp CE, Boniotti A, Masiero M, et al. Toluene diisocyanate- stimulated release of arachidonic acid metabolites in the organ bath of isolated guinea-pig airways. Eur J Pharmacol Environ Toxicol Pharmacol Section 1993; 248: 277-280.

52. Chitano P, Di Blasi P, Lucchini R, et al. The effects of toluene diisocyanate and of capsaicin on human bronchial smooth muscle in vitro. Eur J Pharmacol Environ Toxicol Pharmacol Section 1994; 270: 167-173. 